\title{
Seed Transmission of Pepino mosaic virus and Efficacy of Tomato Seed Disinfection Treatments
}

\author{
Maria del Carmen Córdoba-Sellés, Ana García-Rández, Ana Alfaro-Fernández, and Concepción Jordá- \\ Gutiérrez, Grupo de Virologia-Instituto Agroforestal del Mediterráneo (IAM). Universidad Politécnica de Valencia, \\ Camino de Vera 14, 46022 Valencia, Spain
}

\begin{abstract}
Córdoba-Sellés, M. C., García-Rández, A., Alfaro-Fernández, A., and Jordá-Gutiérrez, C. 2007. Seed transmission of Pepino mosaic virus and efficacy of tomato seed disinfection treatments. Plant Dis. 91:1250-1254.

Rates of seed transmission for Pepino mosaic virus (PepMV) were estimated in seedlings grown from seeds obtained from symptomatic tomato (Lycopersicon esculentum) fruits of plants naturally infected with the virus. The proportion of seeds infected with PepMV was at least $25 \%$ as estimated from enzyme-linked immunosorbent assay (ELISA) analysis of grouped seeds. The seeds from symptomatic fruits were planted, and seedlings at the cotyledon and transplant stage were assayed for PepMV by ELISA. Three of 168 seedlings grown from infected seeds were PepMV-positive, corresponding to a seed-to-seedling transmission rate of $1.84 \%$. Various tomato seed treatments were evaluated for their ability to prevent seed transmission of PepMV. This virus was largely eradicated by immersing the seeds in $10 \%$ trisodium phosphate for $3 \mathrm{~h}$. Although heat treatments of $24 \mathrm{~h}$ at $80^{\circ} \mathrm{C}$ and $48 \mathrm{~h}$ at $74^{\circ} \mathrm{C}$ eliminated PepMV in seedlings, these treatments did not eradicate the virus in whole seeds. The three treatments did not adversely affect seed germination. The results suggest that trisodium phosphate can be used to eradicate PepMV in tomato seed without hindering germination.
\end{abstract}

Additional keywords: pectinase, potexvirus, thermic treatment

Pepino mosaic virus (PepMV) was first reported and characterized in Solanum muricatum Aiton from Peru in 1980 (12), and it is believed to have originated in South America. For many years, it was thought that the presence of PepMV was restricted to Peru and that the virus infected S. muricatum but no other solanaceous crops grown in the region, such as tomato, potato, or eggplant (15). In 1999, PepMV was reported in greenhouse and field-grown tomatoes (Lycopersicon esculentum Mill.) in the Netherlands (26). This potexvirus produced a very complex symptomatology, as symptom development depended on virus isolate, tomato cultivar, temperature, and light intensity. Symptoms generally include a yellow mosaic of varying intensity on the leaves, single yellow spots between veins, green mosaic, leaf bubbling, and other leaf malformations that may be confused with other symptoms resulting from the improper use of growth regulators or Cucumber mosaic virus (CMV) infection. However, the most problematic symptom for growers is fruit mar-

Corresponding author: M. C. Córdoba-Sellés E-mail: mcorsel@ doctor.upv.es

Accepted for publication 17 April 2007.

doi:10.1094/PDIS-91-10-1250

(C) 2007 The American Phytopathological Society bling, that is, the yellowish or greenish spots that appear on ripe fruits after harvest due to an abnormal lycopene distribution or uneven maturation (23), considerably reducing market value.

It is not clear how PepMV was introduced into Europe from South America, but it may have been transported on either pepino plants imported for trial purposes or tomato plants or seeds imported from the Andes for genetic studies. Pepino is grown on a small scale in Spain and experimentally in a few European countries; however, tomato is grown everywhere, and it is an extremely valuable crop. When PepMV was introduced into Europe and North America is not clear either, although since the 1999 growing season, the virus has rapidly spread throughout the principal tomato production zones in Germany (17), Belgium, the United Kingdom (20), Spain (13), Italy (21), the United States and Canada (7), France (3), and Austria (27). The mechanical transmission of PepMV is easy and effective, being spread between plants with contaminated tools, hands, clothing, and by direct plant-to-plant contact. Contact between healthy and infected plants as a result of routine handling during cultivation of the crop is enough to transmit the virus to six plants in a row from a single infected plant, and contact constitutes the main cause for transmission within a plot. In addition, bumble bees used to pollinate tomatoes in plastic houses have been im- plicated in the spread of PepMV between plants in Spain (16). On the other hand, the mechanism for long-distance dissemination of this virus may be the transfer of infected young plants from the nursery to the grower as well as contaminated seeds, infected grafts, cuttings, or fruit. In previous studies (unpublished results), our research team has demonstrated PepMV seed transmission in growth chamber trials, although seed transmission has not been proven under field conditions.

Infected seeds may be a source of primary inoculum for PepMV infections, and combined with routine international distribution of tomato seeds and fruits, this might account for the recent detection of PepMV in Morocco, Finland, Sweden, Slovakia, Bulgaria, Norway, Denmark, Ukraine, Poland, Hungary, Chile (6), and Ecuador (24). Obviously, seed transmission of PepMV is a major concern to the tomato industry. Most tomato seeds sown in the European Union (EU) are produced in third-world countries (China, Thailand, India, Chile, etc.) and shipped to the EU in bulk. Seeds imported by an EU country are tested for quality and pathogens, treated with pesticides, and packaged by the corresponding Official Inspection Service or by accredited seed companies. However, since 1999, PepMV has been found in several consignments of European seeds, and different EU Member States have also discovered PepMV in tomato fruits produced in the EU. On 2 March 2004, the European Committee decreed measures to control the entry and circulation within the EU of tomato seeds infected with PepMV, establishing the inspection and analysis of seeds proceeding from non-EU countries, to detect the presence of the virus before distribution of the seeds within the EU. Member States are therefore obliged to carry out official inspections to detect PepMV in nurseries and seed production stations. An enzyme-linked immunosorbent assay (ELISA)-based seed health test can be used to estimate relatively low levels of PepMV in infected seeds. If the proportion of infected seeds is properly estimated from seed health tests, the risk of introducing PepMV can be assessed once precise rates of seed-to-seedling transmission are known.

Different chemical and physical treatments have been reported to eradicate or significantly reduce the incidence of a 
number of viruses without affecting seed quality. Although some seed companies currently utilize pretreatments for tomato seeds, the details of these seed treatment protocols are proprietary. The objectives of this study were (i) to estimate the rate of seed-to-seedling transmission of PepMV, (ii) to test the efficacy of different chemical and physical seed treatments in eradicating PepMV from tomato seeds, and (iii) to determine the effect of these treatments on tomato seed germination.

\section{MATERIALS AND METHODS}

The tomato seeds used in this study were from a seed mix of unknown cultivars, originating from tomato plants that were naturally infected under field conditions and identified by the presence of fruit marbling. These are referred to as "infected seeds". The infected seeds were provided by horticultural cooperatives from the Almeria, Murcia, and Alicante regions of Spain. Two seed batches were used: one harvested in 2001 (lot-01) and another in 2004 (lot-04). Seeds were cleaned by rinsing in water followed by drying at room temperature on clean muslin.

PepMV detection in whole tomato seeds. To detect the level of virus in the two seed batches, totals of 115 seeds from seed lot-01 and 340 seeds from seed lot-04 were tested using double-antibody sandwich (DAS)-ELISA. Samples of four seeds were soaked for $90 \mathrm{~min}$ in $1 \mathrm{ml}$ of sample extraction buffer, and they were ground with a pestle to obtain the seed extract. DAS-ELISA was carried out in paired wells following the manufacturer's instructions for the PepMV-specific antiserum supplied by DSMZ (Deutsche Sammlung von Mikroorganismen und Zellkulturen $\mathrm{GmbH}$, Braunschweig, Germany) using $100 \mu \mathrm{l}$ of the extracts obtained. Healthy tomato seed extracts and virus-infected tomato leaf samples were included in each ELISA plate to serve as the negative and positive controls, respectively. Absorbance values $\left(A_{405 \mathrm{~nm}}\right)$ were measured in a Titertek Multiskan immunoplate reader (Flow Laboratories, Finland). Values more than twice those for healthy seed extract controls were recorded as infected samples (DAS-ELISA-positive). Otherwise, samples were considered to be noninfected (DAS-ELISA-negative).

PepMV seedlings infection test. To determine seed transmission rates to tomato seedlings, approximately 500 infected seeds per lot were sown in sterile, 24-well trays containing sterilized substrate $(2: 1$ peat:sand) with a single seed per well. Trays were placed inside a growth chamber at $25^{\circ} \mathrm{C}, 16$-h daylight, and $60 \%$ relative humidity. Stringent sanitary measures, including isolation, confinement, careful handling, and insect control, were used to prevent any spurious virus spread. Fourteen days after sowing, one cotyledon from every four plants was pooled (ca. $0.15 \mathrm{~g}$ ) and homogenized in a plastic bag with 3 $\mathrm{ml}$ of the sample extraction buffer. The homogenates were filtered through muslin, and $100-\mu \mathrm{l}$ aliquots were assayed for PepMV by DAS-ELISA as described above. Healthy tomato leaf extracts were included in each ELISA plate to serve as negative controls in the assays of leaf samples. This screening procedure was repeated when the seedlings reached the four-leaf stage. In this case, a portion of the youngest emerged leaf was harvested from each plant in a row. The four leaves sampled per row were pooled and pulverized with a pestle in 1:20 (wt/vol) of extraction buffer as described previously.

Percent incidence from grouped samples was estimated using the formula of Gibbs and Gower $(8), p=1-(1-y / n)^{1 / k}$, where $p$ $=$ probability of transmission by a single PepMV-infected seed, $y=$ number of positive samples, $n=$ total number of samples assayed, and $k=$ number of seeds or seedlings per sample $(k=4)$.

Seed disinfection treatments. To determine the efficacy of seed disinfection treatments in eradicating PepMV from tomato seeds, two replications were made of the following seven treatments, one replication per seed batch. To evaluate the effect of high temperatures to eradicate PepMV, three seed treatments were assayed in which three temperatures were tested: (i) seeds were heated for $24 \mathrm{~h}$ at $80^{\circ} \mathrm{C}$ (T80); (ii) seeds were heated for $48 \mathrm{~h}$ at $74^{\circ} \mathrm{C}$ (T74); and (iii) seeds were heated for $96 \mathrm{~h}$ at $70^{\circ} \mathrm{C}$ (T70). Four disinfectant solutions, proven effective with other viruses, were also tested: (iv) seeds were submerged in a $10 \%$ trisodium phosphate solution for $3 \mathrm{~h}$ (TP); (v) seeds were submerged in a $3 \mathrm{~g} /$ liter pectinase solution (from Rhizopus sp., SIGMA-ALDRICH, Germany) in distilled water for $24 \mathrm{~h}(\mathrm{P})$; (vi) seeds were submerged in a $3 \mathrm{~g} / \mathrm{liter}$ pectinase solution supplemented with $2 \%$ $\mathrm{HCl}$ in distilled water for $24 \mathrm{~h}(\mathrm{PH})$; and (vii) seeds were submerged in a $3 \mathrm{~g} /$ liter pectinase solution supplemented with $2 \%$ $\mathrm{HCl}$ and $30 \%$ commercial bleach in distilled water for $24 \mathrm{~h}$ (PHB). For each chemical treatment, a mesh tea strainer with the seeds was immersed in $100 \mathrm{ml}$ of the disinfectant solution in a $250-\mathrm{ml}$ glass beaker. The mouth of the beaker was covered with Parafilm (Pechiney Plastic Packaging, Menasha, WI, USA), and the beaker was placed on an orbital shaker at $220 \mathrm{rpm}$ for the specified duration at room temperature. Then the seeds were immediately triple-rinsed in the tea strainer using sterile deionized water, dried on sterile paper towels, and placed in a sterile petri plate. For each seed lot, approximately 200 tomato seeds per treatment were used, and for the control group (no treatment [NT]), the same number of seeds per lot was triple-rinsed in sterile deionized water and dried. Half of the treated seeds were as- sayed for PepMV as whole seeds as described above, and the other half was sown and tested for PepMV in the same manner as in the seedling infection test.

For each physical or chemical treatment, the germination rate was calculated by counting seedlings about 25 days after sowing and comparing with the germination values obtained from untreated tomato seeds for both seed batches.

Statistical analysis. In all experiments, absorbance data from samples of each ELISA plate were analyzed using the multifactorial ANOVA procedure in STATGRAPHICS Plus for Windows (Version 5.1; Manugistics Inc., Rockville, MD, USA). The "growth stage at the time of analysis" and "seed treatment" were considered fixed effects. Fisher's protected least significance difference (LSD; $P<$ 0.05 ) procedure was used to determine which means were significantly different from the others. The same statistical procedure was conducted with the germination data obtained. In this case, "seed treatment" and "seed lot assayed" were considered fixed effects.

\section{RESULTS}

PepMV infection of tomato seeds from infected fruit. As the results obtained in the first trial (lot-01) (data not shown) were essentially identical to those of the second (lot-04), only results for serological analysis of the second trial are shown (Table 1). Eighty-five groups of four untreated seeds tested, corresponding to 340 untreated seeds, gave positive results for PepMV by ELISA in the whole seed assay. If only one seed per group of four was infected, the seed infection rate was $25 \%$. No obvious symptom or defect was observed in the tomato seeds.

Seed transmission of PepMV. A total of 217 untreated seeds from lot-04 were planted, and 168 produced seedlings (Table 1). Only three samples, each comprised of tissue from four seedlings, tested positive for PepMV by ELISA. These data indicate that PepMV is seed-transmitted, the rate of transmission being nearly $2 \%$ as calculated using the formula of Gibbs and Gower (8). None of the ELISA-positive tomato seedlings had obvious symptoms of PepMV infection.

The stage of plant growth at the time of ELISA analysis significantly $(P=0.0000)$ affected the PepMV infection rate (measured as absorbance obtained in ELISA) of the untreated tomato lots. Absorbance values for duplicate samples of 42 negative controls ranged from -0.016 to 0.039 , with a mean value of 0.007 . Absorbance values of duplicate samples of 42 positive controls ranged from 0.11 to 0.72 , with a mean value of 0.362 . The average absorbance value for whole seed samples was 28 times higher than that obtained with cotyledon or leaf samples (Table 2). The mean absorbance of untreated seed samples was 0.252 
\pm 0.004 , and for cotyledons and leaves, $0.014 \pm 0.008$ and $0.01 \pm 0.007$, respectively. There were no significant differences in absorbance between the analysis performed at the cotyledon or at the transplant stage. For this reason, results of cotyledon analysis were not used in later statistical analyses.

Efficacy of seed disinfection treatments. The incidence of seed infection after various disinfection treatments in addition to the transmission rates of PepMV from treated seeds to seedlings are provided in Table 1. Only TP, PH, and PHB totally reduced PepMV detection of the whole seed assay. The seed infection detected after subjecting infected seed to the other treatments remained in the same range as the nontreated seed lots. By contrast, reduction in the incidence of PepMV in seedlings obtained with all seed treatments was significant except with T70.

Treating seeds with T80 or T74 did not affect the percentage of infected seeds that remained in the same range as the nontreated seeds. However, T80 reduced background ELISA absorbance values by $60 \%$ compared with untreated seeds (Table 2 ), and no infection was found in seedlings grown from these seeds (Table 1). T74 led to an absorbance decrease of about $14 \%$ compared with untreated seed samples (Table 2). As with T80, no infected seedlings resulted from these treated seeds (Table 1). Treating seeds with T70 led to a slight reduction in infection at the whole seed stage, between 23 and $92 \%$ of the seeds being infected (Table 1). Moreover, this treatment resulted in a $42.5 \%$ reduction in treated-seed absorbance $(0.144 \pm$ 0.008) compared with that of the untreated seed (Table 2); nevertheless, the probability of detecting an infected seedling with this treatment remained at 0.016 (Table 1).

TP treated seeds tested negative for PepMV (absorbance reduction of 98.2\%), and no infected seedlings were detected (Table 1). The absorbance value of the seed samples subjected to $\mathrm{P}$ was only re- duced by $3.08 \%(0.244 \pm 0.008)$ compared with the untreated seeds (Table 2), and the infection level remained between 25 and $100 \%$ of the analyzed seeds (Table 1). Nonetheless, seedlings were not infected from treated seeds. When pectinase treatment was supplemented with $\mathrm{HCl}(\mathrm{PH})$, infection was eliminated in the whole-seed stage (Table 1), and there were no infected seedlings from the treated seeds. On the other hand, when bleach was added to $\mathrm{PH}$ (PHB), no whole seed sample tested positive by ELISA (absorbance value of 0.004 \pm 0.008 ) (Table 2). This treatment reduced absorbance values by $98.2 \%$ relative to untreated seeds, exactly the same as TP. However, no seeds germinated after this treatment, so it was rejected even though

Table 2. Absorbance values for seed and seedlings submitted to seven disinfection treatments and for no-treated lots, assayed for Pepino mosaic virus (PepMV) using an enzyme-linked immunosorbent assay (ELISA)-based seed health test

\begin{tabular}{lccccc}
\hline & & & \multicolumn{3}{c}{ Absorbance values $^{\mathbf{w}}$} \\
\cline { 3 - 6 } Growth stage $^{\mathbf{x}}$ & & & & $\begin{array}{c}\text { Standard } \\
\text { deviation }\end{array}$ & \multicolumn{1}{c}{ Range } \\
\hline Whole seed & Treatment $^{\mathbf{y}}$ & $\boldsymbol{n}^{\mathbf{z}}$ & Mean & 0.004 & $0.243-0.261$ \\
& NT & 84 & 0.252 & 0.008 & $0.082-0.115$ \\
& T80 & 25 & 0.098 & 0.009 & $0.200-0.235$ \\
& T74 & 22 & 0.218 & 0.008 & $0.128-0.161$ \\
& T70 & 25 & 0.144 & 0.008 & $-0.013-0.022$ \\
& TP & 23 & 0.004 & 0.008 & $0.227-0.261$ \\
& P & 25 & 0.244 & 0.008 & $-0.003-0.029$ \\
& PH & 27 & 0.013 & 0.008 & $-0.011-0.032$ \\
& PHB & 31 & 0.004 & 0.007 & $-0.003-0.024$ \\
& NT & 35 & 0.010 & 0.007 & $-0.002-0.027$ \\
& T80 & 31 & 0.013 & 0.010 & $-0.013-0.034$ \\
& T74 & 12 & 0.010 & 0.033 \\
& T70 & 16 & 0.012 & 0.008 & $-0.011-0.022$ \\
& TP & 24 & 0.005 & 0.009 & $-0.007-0.028$ \\
& P & 21 & 0.010 & 0.009 & $-0.009-0.028$ \\
\hline
\end{tabular}

w Absorbance at $405 \mathrm{~nm}$

${ }^{x}$ Growth stage at time of ELISA: whole seed or four fully developed leaves.

${ }^{y}$ Disinfection treatments used: NT, no treatment; T80, heat treatment at $80^{\circ} \mathrm{C}$ for $24 \mathrm{~h}$; T74, heat treatment at $74^{\circ} \mathrm{C}$ for $48 \mathrm{~h}$; T70, heat treatment at $70^{\circ} \mathrm{C}$ for $96 \mathrm{~h}$; TP, immersion in a $10 \%$ trisodium phosphate solution for $3 \mathrm{~h} ; \mathrm{P}$, immersion in a $3 \mathrm{~g} /$ liter pectinase solution for $24 \mathrm{~h}$; $\mathrm{PH}$, immersion in a 3 $\mathrm{g} /$ liter pectinase and $2 \% \mathrm{HCl}$ solution for $24 \mathrm{~h}$; $\mathrm{PHB}$, immersion in a $3 \mathrm{~g} /$ liter pectinase, $2 \% \mathrm{HCl}$, and $30 \%$ commercial bleach solution for $24 \mathrm{~h}$.

${ }^{\mathrm{z}}$ Number of samples tested by ELISA. A sample comprised four tomato seed in case of testing whole seed or four leaves in case of testing tomato seedlings by ELISA.

Table 1. Efficacy of seven disinfection seed treatments for eradication of Pepino mosaic virus (PepMV) from infected tomato seed, emergence rates (\%) obtained after each seed treatment, and probability of seedling infection in seed lot-04

\begin{tabular}{|c|c|c|c|c|c|c|c|}
\hline \multirow[b]{2}{*}{ Treatment $^{\mathrm{w}}$} & \multicolumn{3}{|c|}{ Seeds } & \multicolumn{4}{|c|}{ Seedlings } \\
\hline & Tested $^{\mathrm{x}}$ & $\begin{array}{c}\text { Positive } \\
\text { samples }^{\mathrm{y}}\end{array}$ & $\begin{array}{l}\text { Range of seed } \\
\text { infection }(\%)\end{array}$ & $\begin{array}{c}\text { Emergence } \\
(\%)\end{array}$ & Tested $^{x}$ & $\begin{array}{c}\text { Positive } \\
\text { samples }^{y}\end{array}$ & $\begin{array}{l}\text { Probability } \\
\text { of infection }\end{array}$ \\
\hline NT & 340 & 85 & $25-100$ & 77.38 & 168 & 3 & 0.018 \\
\hline T80 & 100 & 25 & $25-100$ & 81.25 & 148 & 0 & 0.000 \\
\hline T74 & 88 & 22 & $25-100$ & 80.90 & 44 & 0 & 0.000 \\
\hline T70 & 100 & 23 & 23-92 & 75.00 & 64 & 1 & 0.016 \\
\hline TP & 100 & 0 & 0 & 85.00 & 100 & 0 & 0.000 \\
\hline $\mathrm{P}$ & 100 & 25 & $25-100$ & 84.38 & 84 & 0 & 0.000 \\
\hline $\mathrm{PH}$ & 108 & 0 & 0 & 67.86 & 76 & 0 & 0.000 \\
\hline PHB & 124 & 0 & 0 & 0.00 & 0 & 0 & 0.000 \\
\hline
\end{tabular}

${ }^{\text {w}}$ Disinfection treatments used: NT, no treatment; T80, heat treatment at $80^{\circ} \mathrm{C}$ for $24 \mathrm{~h}$; T74, heat treatment at $74^{\circ} \mathrm{C}$ for $48 \mathrm{~h}$; T70, heat treatment at $70^{\circ} \mathrm{C}$ for $96 \mathrm{~h}$; TP, immersion in a $10 \%$ trisodium phosphate solution for $3 \mathrm{~h} ; \mathrm{P}$, immersion in a $3 \mathrm{~g} /$ liter pectinase solution for $24 \mathrm{~h}$; $\mathrm{PH}$, immersion in a $3 \mathrm{~g} /$ liter pectinase and $2 \% \mathrm{HCl}$ solution for $24 \mathrm{~h}$; PHB, immersion in a $3 \mathrm{~g} /$ liter pectinase, $2 \% \mathrm{HCl}$, and $30 \%$ commercial bleach solution for $24 \mathrm{~h}$.

${ }^{\mathrm{x}}$ Number of whole seeds/seedlings tested by enzyme-linked immunosorbent assay (ELISA) after each disinfection treatment.

${ }^{y}$ Number of PepMV-positive grouped seed/leaf samples. A sample corresponds to a group of four whole seeds/leaves from four seedlings.

${ }^{\mathrm{z}}$ Probability of infected seedlings grown from infected seeds (i.e., rate of seed-to-seedling PepMV transmission) calculated using the formula of Gibbs and Gower (8) to estimate proportions from group samples. 
In all the seeds subjected to these treatments, P, PH, and PHB caused seed pregermination during the treatment period. For both seed lots, four seed treatments (T80, T74, TP, and P) increased the germination rate (Table 3 ). TP had the most favorable effect in seed germination, which increased by $18.7 \%$ (lot- 01 ) and $7.62 \%$ (lot-04), respectively, compared with untreated seed lots (Table 3 ). The second best germination rate resulted from $P$, which increased germination around 7\% in both seed lots (Table 3). By contrast, T70, PH, and PHB reduced germination rates (Table $3)$. PHB led to the greatest reduction recorded. PHB proved to be extremely harmful to the tomato seeds, since no seed disinfected with it germinated successfully.

\section{DISCUSSION}

To the authors' knowledge, this is the first report to be published on seed transmission of PepMV. Previous studies indicated that certain PepMV isolates could not be seed-transmitted in tomato cv. Camone (23). The small size of the sample previously tested, 52 seedlings, might account for the very low transmission rate in the host. These authors suggested the possibility of seed transmission among other tomato cultivars and other Lycopersicon species used for grafting to L. esculentum. It is not uncommon with viruses to have different seed transmission rates among different plant host species or cultivars, e.g., Pea seedborne mosaic virus (PSbMV) or Barley stripe mosaic virus (BSMV) $(5,28)$. We detected PepMV in at least $25 \%$ of the tested tomato seeds, but only $2 \%$ of the progeny derived from the same seed batch. Similarly, previous studies determined that the viral transmission by seed does not necessarily correlate with the rate of infected progeny seedlings $(10,19)$. The rate of seed transmission is not necessarily a sound indicator of epidemiological significance. Even low rates of seed transmission, in conjunction with secondary spread by insect vectors or mechanical transmission, can lead to the introduction of viruses into new areas, producing viral disease epidemics (4). Lettuce production is severely affected by Lettuce mosaic virus (LMV) at a $0.001 \%$ incidence of seed transmission given subsequent virus spread by aphid vectors (22). Similarly low rates of seed transmission are also sufficient for epidemics of Bean yellow mosaic virus (BYMV) in subterranean clover pastures (11). Thus, even extremely low rates of seed transmission can facilitate the introduction of viruses into previously noninfected crop production areas (10).

Our tests with PepMV demonstrated low levels of seed transmission; nevertheless, PepMV is an extremely stable and persistent virus, with relatively high rates of unintentional mechanical transmission, quite similar to Tobacco mosaic virus
(TMV). Growers reported PepMV to spread much faster than another potexvirus, Potato virus $X$ (PVX), in glasshouses, and just as fast as Tomato mosaic virus (ToMV). Like TMV, ToMV remains viable when carried in contaminants on the seed surface, and seedling infection occurs primarily by mechanical transmission, especially during handling of the seedlings $(1,25)$.

Based on the results of this study, we can conclude that the seedborne nature of PepMV in tomato has contributed both to its introduction into previously unaffected tomato production areas and to its rapid spread in tomato greenhouses around the world. It is possible that the virus was introduced to greenhouses with contaminated tomato seeds, infected seedlings/plants, and perhaps infected fruits sent for packing in tomato nurseries. PepMV can easily be transmitted mechanically to tomato seedlings from a contaminated seed source, and thus the infected seed is considered a potential source of initial virus inoculum. Contaminated trays or tools used in greenhouses and human contact may be other avenues of introduction. Under certain environmental conditions, PepMV will spread rapidly through planting material from a few primary infection sites, due to its transmission by contact, if initial infections are symptomless and no precautions are taken (16) and if emergency controls currently in place in EU Member States are not maintained. Although the eradication of PepMV has been reported in many EU countries, the virus persists in others since visual symptoms on tomato are often absent, and PepMV is easily spread by mechanical and other means if the proper precautions are not taken.

There are only limited options to combat this highly contagious disease. The current disease management strategy to prevent PepMV transmission in greenhouse tomato production is by cultural practices. These practices include the use of certified PepMV-free tomato seeds and the elimina- tion of any symptomatic plants. For several viruses, resistant cultivars have been used to successfully control them. Unfortunately, current tomato cultivars have no resistance to PepMV infection. Ideally, PepMV could be controlled by preventing the causal agent from entering the field. Infected seeds are a potential risk for introducing the virus at production sites, as well as infected transplants, contaminated implements, and possibly, infected weeds $(2,14)$. To prevent viral transmission, precautions must be taken to identify contaminated batches of seeds and fruits. As testing of all seedlings is impractical, regulations should mandate testing to ensure the seeds are PepMV-free. If PepMV is detected in consignments of tomato seeds from European Member States, this indicates that the current seed testing regime is not detecting all seed batches that pose a threat. Based on the findings of this study, PepMV is seed-transmitted in seeds harvested from fruits with the typical marbling symptom. It is both essential and feasible to eliminate symptomatic fruits as well as selected tomato seedlings from between field rows, which have germinated from fruit that fell to the ground There is no way at this time to detect and cull the fruits that are symptomless carriers of PepMV. Therefore, we recommend not harvesting seeds from fruits in the vicinity of symptomatic tomato plants. The safest approach is clearly to harvest seeds only from fields that have no PepMV infection.

Experiments conducted for this study showed that seedlings grown from infected tomato seeds might become infected at low rates $(<2 \%)$ if the seeds were not cleaned or if they were cleaned poorly. To prevent seed-transmission and considering the difficulty in guaranteeing that harvested seeds are not contaminated with PepMV, regulations for an additional seed treatment should be implemented.

Our results suggest that thermic seed treatments are ineffective in eliminating PepMV. No thermic treatment assayed reduced the fraction of whole seeds that
Table 3. Effect of seed treatments on tomato seed germination rates from both seed batches

\begin{tabular}{lccccc}
\hline & \multicolumn{2}{c}{ Lot-01 } & & \multicolumn{2}{c}{ Lot-04 } \\
\cline { 2 - 3 } \cline { 5 - 6 } Treatment $^{\mathbf{x}}$ & Germination $^{\mathbf{y}}$ & Variation rate $^{\mathbf{z}}$ & & Germination $^{\mathbf{y}}$ & Variation rate $^{\mathbf{z}}$ \\
\hline NT & 60.00 & $\ldots$ & & 77.38 & $\ldots$ \\
T80 & 65.06 & 5.06 & & 81.25 & 3.87 \\
T74 & 70.75 & 10.75 & & 80.90 & 3.52 \\
T70 & 52.59 & -7.41 & & 75.00 & -2.38 \\
TP & 78.70 & 18.70 & & 85.00 & 7.62 \\
P & 67.74 & 7.74 & & 84.38 & 7.00 \\
PH & 54.60 & 5.40 & & 67.86 & -9.52 \\
PHB & 0.00 & -60.00 & & 0.00 & -77.38 \\
\hline
\end{tabular}

${ }^{\mathrm{x}}$ Disinfection treatments used: NT, no treatment; T80, heat treatment at $80^{\circ} \mathrm{C}$ for $24 \mathrm{~h}$; T74, heat treatment at $74^{\circ} \mathrm{C}$ for $48 \mathrm{~h}$; T70, heat treatment at $70^{\circ} \mathrm{C}$ for $96 \mathrm{~h}$; TP, immersion in a $10 \%$ trisodium phosphate solution for $3 \mathrm{~h}$; $\mathrm{P}$, immersion in a $3 \mathrm{~g} /$ liter pectinase solution for $24 \mathrm{~h}$; $\mathrm{PH}$, immersion in a 3 $\mathrm{g} /$ liter pectinase and $2 \% \mathrm{HCl}$ solution for $24 \mathrm{~h}$; PHB, immersion in a $3 \mathrm{~g} /$ liter pectinase, $2 \% \mathrm{HCl}$, and $30 \%$ commercial bleach solution for $24 \mathrm{~h}$.

${ }^{y}$ Germination rates were recorded 25 days after sowing.

${ }^{\mathrm{z}}$ Variation in the germination rate obtained with seed treated related to the germination rate of the untreated seed group. 
were ELISA positive for PepMV, but the number of infected seedlings was reduced. T80 and T74 reduced virus incidence in seedlings, but we were not able to rule out seed transmission given the small number of seedlings tested, 148 and 44 seedlings, respectively. The transmission rates were apparently reduced since no infected plants were obtained after seed treatment, but a higher number of seedlings should be tested to confirm the absence of transmission. The high stability of PepMV is the reason why T70 was truly ineffective. The virus was not eradicated from all seeds; there was still a low level of seed transmission $(1.6 \%)$, while germination was clearly affected with this thermic treatment.

Results of the chemical seed treatment trials indicate that a PepMV-infected tomato seed lot could be treated by immersion in a $10 \%$ trisodium phosphate solution for $3 \mathrm{~h}$, not only to eradicate PepMV from the seed but also to prevent transmission to seedlings while favoring seed germination. Trisodium phosphate pretreatment has been used to eliminate other viruses such as TMV from infected tomato seeds. It does not affect seed germination rates yet contributes to healthy tomato plants (9). All the chemical treatments, except $P$, removed the virus from the seed. These data indicate that PepMV is transmitted via seeds, perhaps as a result of contaminants and debris on the seed surface. It is not known where PepMV is located in the seed, but the elimination of the virus from seed batches using a trisodium phosphate treatment suggests the virus is carried predominantly on the seed surface. Presumably tomato seeds acquire PepMV particles during their development on the infected plant. It is possible that the germinating seedlings are inoculated with virus located on the seed coat as it emerges from the seed. This is similar to TMV transmission from infected tomato seeds, where the embryo is not infected and the virus is transmitted to seedlings from the seed coat through small wounds (18). This mechanism might also account for the low rates of PepMV seed transmission, even though the level of seed infection is quite high.

Pectinase was unable to remove virus on its own from the whole seed infected; $\mathrm{HCl}$ was needed to remove the virus completely, but emergence was reduced by this treatment. In fact, when bleach was added to this disinfectant solution (PHB), no seed disinfected with this treatment germinated. By contrast, we found $\mathrm{P}$ to be as effective as TP in the transplant stage, with no infected seedlings and with a positive effect on germination rates. As with T80 and $\mathrm{T} 74$, the transmission rate after treating seeds with pectinase was apparently reduced, since no plants were infected. However, only 84 seedlings were tested, and a higher number may need to be studied to confirm this result.

The most interesting of the seven disinfection treatments tested was TP, because it had the most favorable effect on seed disinfection and cleaning as well as on the germination rate of treated seeds. Using accurately controlled parameters, trisodium phosphate can be used to eradicate PepMV in tomato seeds without hindering germination. Moreover, TP is the easiest and most rapid of all the treatments assayed, only $3 \mathrm{~h}$ being sufficient to completely eliminate PepMV in whole seeds.

Research is needed to evaluate specific temperatures and durations of thermic treatments with effectiveness to eradicate PepMV in whole tomato seeds. In addition, the disinfection treatments studied here must be evaluated using a broader range of tomato cultivars infected with different PepMV isolates. Such studies are needed to determine the optimum conditions to avoid seed injury while maximizing the control of this seedborne virus. Adequately tested seed plus hygiene measures could be used to declare propagation sites free of PepMV. We believe that a legislated protocol for seed treatment and testing is desirable. There are insufficient data on the factors influencing the efficacy of seed treatments, and precise requirements for testing seeds for PepMV would need to be decided and formalized so that the effectiveness of the seed testing would not be called into question by any organization or country. More research may need to be undertaken to optimize seed testing protocols against PepMV infection so as to control and eradicate the disease.

\section{LITERATURE CITED}

1. Broadbent, L. 1965. The epidemiology of tomato mosaic. XI. Seed-transmission of TMV. Ann. Appl. Biol. 56:177-205.

2. Córdoba, M. C., Martínez-Priego, L., and Jordá, C. 2004. New natural hosts of Pepino mosaic virus in Spain. Plant Dis. 88:906.

3. Cotillon, A. C., Girard, M., and Ducouret, S. 2002. Complete nucleotide sequence of genomic RNA of a French isolate of Pepino mosaic virus (PepMV). Arch. Virol. 147:2231-2238.

4. Dinant, S., and Lot, H. 1992. Lettuce mosaic virus: A review. Plant Pathol. 41:528-542.

5. Edwards, M. C. 1995. Mapping of the seed transmission determinants of Barley stripe mosaic virus. Mol. Plant-Microbe Interact. 8:906915.

6. EPPO. EPPO Alert list-Viruses. Pepino mosaic potexvirus - a New Virus of Tomato Introduced into Europe. 2005. Available online: http:// www.eppo.org/quarantine/alert.list/viruses/pep mvo.htm. (Date of last access: April 2006)

7. French, C. J., Bouthillier, M., Bernardy, M., Ferguson, G., Sabourin, M., Johnson, R. C., Masters, C., Godkin, S., and Mumford, R. 2001. First report of Pepino mosaic virus in Canada and the United States. Plant Dis. 85:1121.

8. Gibbs, A. J., and Gower, J. C. 1960. The use of a multiple-transfer method in plant virus transmission studies: Some statistical points arising in the analysis of results. Ann. Appl. Biol. 48:75-83.
9. Green, S. K., Hwang, L. L., and Kuo, Y. K. 1987. Epidemiology of tomato mosaic virus in Taiwan and identification of strains. J. Plant Dis. Prot. 94:386-387.

10. Johansen, E., Edwards, M. C., and Hampton, R. O. 1994. Seed transmission of viruses: Current perspectives. Annu. Rev. Phytopathol. 32:363-386.

11. Jones, R. A. C. 1994. Infection of subterranean clover with bean yellow mosaic potyvirus: Losses in herbage and seed yields caused and patterns of virus spread. Aust. J. Agric. Res. 45:1395-1412.

12. Jones, R. A. C., Koenig, R., and Lesemann, D. E. 1980. Pepino mosaic virus, a new potexvirus from pepino (Solanum muricatum). Ann. Appl. Biol. 94:61-68.

13. Jordá, C., Lázaro-Pérez, A., Martínez-Culebras, P., Abad, P., Lacasa, A., and Guerrero, M. M. 2001. First report of Pepino mosaic virus on tomato in Spain. Plant Dis. 85:1292.

14. Jordá, C., Lázaro-Pérez, A., MartínezCulebras, P. V., and Lacasa, A. 2001. First report of Pepino mosaic virus on natural hosts. Plant Dis. 85:1292.

15. Koenig, R., Lesemann, D. E., and Jones, R. A. C., eds. 1989. Pepino mosaic virus. AAB Descriptions of Plant Viruses No. 350, Warwick, UK.

16. Lacasa, A., Guerrero, M. M., Hita, I., Martínez, M. A., Jordá, C., Bielza, P., Contreras, J., Alcazar, A., and Cano, A. 2003. Implication of bumble bees (Bombus spp.) on Pepino mosaic virus (PepMV) spread on tomato crops. Plagas 29:393-403.

17. Lesemann, D. E., Dalchow, J., Winter, S., and Pfeilstetter, E. 2000. Occurrence of Pepino mosaic virus in European tomato crops: Identification, etiology and epidemiology. Mitt. Biol. Bundesanst, Berlin-Dahlem 376:323.

18. Mathews, R. E. F., ed. 1991. Plant Virology. 3rd ed. Academic Press, New York.

19. Mink, G. I. 1993. Pollen- and seed-transmitted viruses and viroids. Annu. Rev. Phytopathol. 31:375-402.

20. Mumford, R. A., and Metcalfe, E. J. 2001. The partial sequencing of the genomic RNA of a UK isolate of Pepino mosaic virus and the comparison of the coat protein sequence with other isolates from Europe and Peru. Arch. Virol. 146:2455-2460.

21. Roggero, P., Masenga, V., Lenzi, R., Coghe, F., Ena, S., and Winter, S. 2001. First report of Pepino mosaic virus in tomato in Italy. Plant Pathol. 50:798.

22. Ryder, E. J. 1973. Seed transmission of lettuce mosaic virus in mosaic resistant lettuce. J. Am. Soc. Hortic. Sci. 98:610-614.

23. Salomone, A., and Roggero, P. 2002. Host range, seed transmission and detection by ELISA and lateral flow of an Italian isolate of Pepino mosaic virus. J. Plant Pathol. 84:65-68.

24. Soler, S., López, C., and Nuez, F. 2005. Natural occurrence of viruses in Lycopersicon spp. in Ecuador. Plant Dis. 89:1244.

25. Taylor, R. H., Grogan, R. G., and Kimble, K. A. 1961. Transmission of tobacco mosaic virus in tomato seed. Phytopathology 51:837-842.

26. Van der Vlugt, R. A. A., Stijger, C. C. M. M. Verhoeven, J. Th. J., and Lesemann, D. E. 2000. First report of Pepino mosaic virus in tomato. Plant Dis. 84:103.

27. Verhoeven, J. Th. J., van der Vlugt, R. A. A. and Roenhorst, J. W. 2003. High similarity between tomato isolates of Pepino mosaic virus suggests a common origin. Eur. J. Plant Pathol. 109:419-425.

28. Wang, D., Woods, R. D., Cockbain, A. J., Maule, A. J., and Biddle, A. J. 1993. The susceptibility of pea cultivars to pea seed borne mosaic virus infection and virus seed transmission in the UK. Plant Pathol. 42:42-47. 